\title{
Phragmoplast-mediated cytokinesis in Trentepohlia: results of TEM and immunofluorescence cytochemistry
}

\author{
1,2 Department of Biological \\ Sciences ${ }^{1}$ and School of \\ Veterinary Medicine², \\ Louisiana State \\ University, Baton Rouge, \\ LA 70803, USA \\ 3 Department of Biology, \\ University of Louisiana at \\ Lafayette, Lafayette, \\ LA 70504, USA
}

\author{
Russell L. Chapman, ${ }^{1}$ Olga Borkhsenious, ${ }^{2}$ Roy C. Brown, ${ }^{3}$ \\ Margaret C. Henk ${ }^{1}$ and Debra A. Waters ${ }^{1}$
}

Author for correspondence: Russell L. Chapman. Tel: +1 225578 3457. Fax: + 12255785328. e-mail: chapman@su.edu

\begin{abstract}
This paper reports transmission electron microscopy (TEM) and immunofluorescence evidence for phragmoplast-mediated cytokinesis in the green alga, Trentepohlia (Ulvophyceae, Chlorophyta). This type of cytokinesis is normally found only in land plants and some charophycean green algae. Earlier TEM work documented a phragmoplast in another trentepohlialean alga, Cephaleuros. Numerous molecular studies have shown that both Trentepohlia and Cephaleuros are clearly not in the charophycean (streptophyte) lineage of green algae. Also, details of vegetative cytokinesis in Trentepohlia and Cephaleuros indicate differences from the processes and structures observed in the streptophytes. Parallel evolution could be the explanation for a phragmoplast-mediated cytokinesis in both the chlorophycean Trentepohliales and the streptophyte lineage of charophycean green algae and land plants.
\end{abstract}

Keywords: Trentepohlia, Trentepohliales, phragmoplast, immunofluorescence cytochemistry

\section{INTRODUCTION}

Over the last decade, molecular studies have shown that (1) green algae and land plants share a common ancestor, (2) there are two major lineages of green algae, the charophycean and chlorophycean, and (3) the charophycean green algae are the closest relatives to the land plants (Chapman et al., 1998; Graham, 1993; Graham \& Kaneko, 1991; Huss \& Kranz, 1997; Kranz et al., 1995; Manhart, 1994; McCourt, 1995; Mishler et al., 1994). Some charophycean green algae have a phragmoplast-type cell division, the type basic to all land plants. This important cytokinetic process has been documented within three of the orders of charophycean algae (Coleochaetales, Charales and Zygnematales), but not in the other two orders (Chlorokybales and Klebsormidiales), nor in Chaeto-

\footnotetext{
This paper was presented at the XIIIth meeting of the International Society for Evolutionary Protistology in České Budějovice, Czech Republic, 31 July-4 August 2000.

High-resolution TIFF files of Figs 1-6 are available as supplementary data in IJSEM Online (http://ijs.sgmjournals.org/).

Abbreviation: TEM, transmission electron microscopy.
}

sphaeridium, an alga in the Coleochaetales (Cimino et al., 2000a, but see also Sluiman \& Guihal, 1999; Cimino et al., 2000b; Sluiman, 2000). A well-developed phragmoplast-type cell division has been documented (Chapman \& Henk, 1986), however, in the subaerial green alga, Cephaleuros parasiticus (Trentepohliales), a taxon that molecular data have unequivocally placed in the chlorophycean (rather than charophycean) lineage of green algae (Chapman \& Avery, 1989; Chapman et al., 1995; López-Bautista, 2000). Resolution of this conundrum requires further comparative analysis of basic cellular processes in two separate and distinct developmental evolutionary lineages.

The inexplicable discovery of phragmoplast-mediated cytokinesis in the Trentepohliales broadens the range of green algal orders in which the basic details of this type of cytokinesis can be studied. Elegant ultrastructural studies (Brown et al., 1994; Fowke \& PickettHeaps, 1969a, b; Galway \& Hardham, 1986; Grolig, 1992; Marchant \& Pickett-Heaps, 1973; McIntosh et al., 1995; Pickett-Heaps, 1967; Pickett-Heaps \& Marchant, 1972; Pickett-Heaps \& Wetherbee, 1987) have described diverse phragmoplast-type cell divisions in various charophycean green algae. The unique 


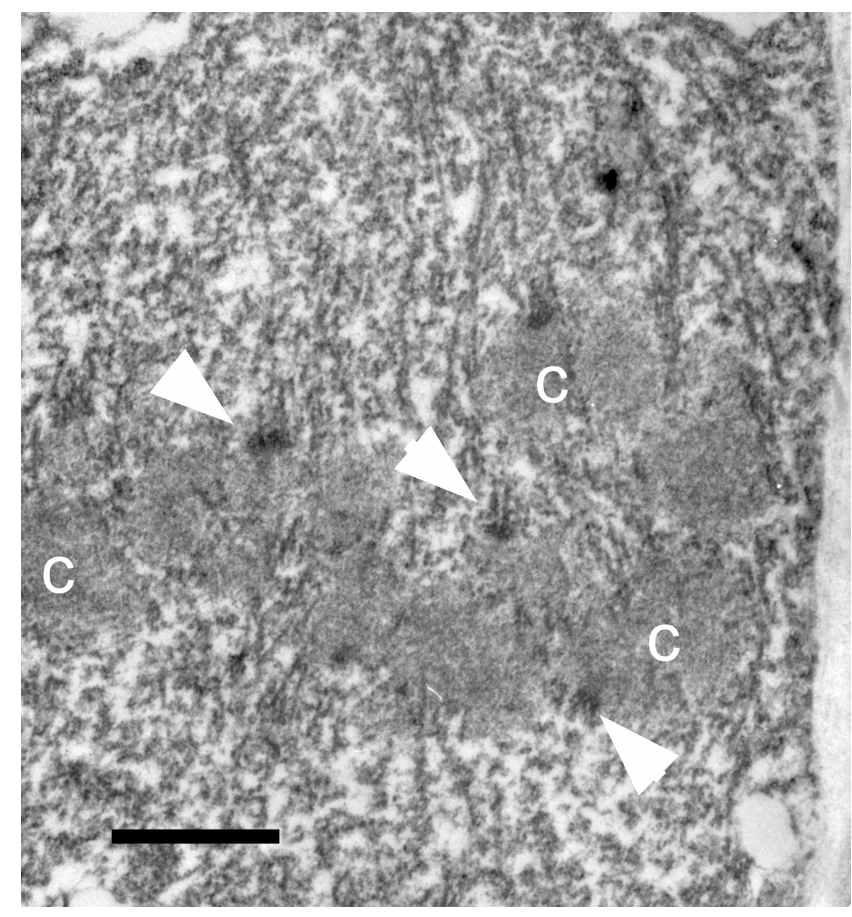

Fig. 1. TEM section through metaphase plate showing condensed chromatin (C) with several dark kinetochore-like structures (arrowheads) at sites of microtubule abutment. Microtubules are present, but there are no associated small vesicles. Bar, $1 \mu \mathrm{m}$.

role of the phragmoplast in cell division in higher plants has been appreciated for more than three decades, and the variations in cytokinesis in the lower land plants (i.e. the bryophytes) have been beautifully demonstrated in ultrastructural and light microscopic studies (Brown \& Lemmon, 1988, 1993, 1997a). However, to grasp fully the diversification and developmental differences in cytokinesis, we must look to the green algae in which the process originated and developed. A paper by Pickett-Heaps et al. (1999) examines the cytokinetic process in the charophycean alga, Spirogyra, as a possible model for the evolution of the phragmoplast. Further elucidation of phragmoplast-mediated cytokinesis in the enigmatic trentepohlialean green algae should provide additional clues to the evolution of this process. In this paper, we report that transmission electron microscopy (TEM) and immunofluorescence cytochemical studies revealed phragmoplast-mediated cytokinesis in a second trentepohlialean taxon, Trentepohlia odorata (Wiggers) Whitrock.

\section{METHODS}

For TEM examination, Trentepohlia odorata (CCAP 483/4) cultures growing on MWH media (Nichols, 1973) were maintained at ambient room temperature (approx. $22^{\circ} \mathrm{C}$ ) under continuous illumination. Thalli were excised together with the agarose substrate. The resulting small cubes were fixed in two portions of $0.5 \%$ glutaraldehyde with $2 \%$ formaldehyde and $1 \%$ osmium tetroxide in $0.05 \mathrm{M}$ sodium cacodylate buffer,

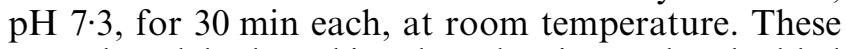
were then dehydrated in ethanol series, and embedded in LR White resin, after which thin sections were prepared with a Reichert microtome, stained with uranyl acetate and lead citrate, and observed with a JEOL-100 CX electron microscope in the Socolofsky Microscopy Center at Lousiana State University, Baton Rouge.

The use of fluorescence confocal microscopy techniques (Brown \& Lemmon, 1993, 1995; Panteris et al., 1991; Staehelin \& Hepler, 1996) allowed rapid survey of large numbers of Trentepohlia odorata filaments. Trentepohlia odorata was grown in liquid MBV medium (Friedl, 1989) at $25^{\circ} \mathrm{C}$ on an 11:13 light:dark regime. Previous studies (cf. Bouillion, 1985) on attempted synchronization of cell division in Trentepohlia and Cephaleuros determined that the optimal time for observing cell division in this alga was $5 \mathrm{~h}$ after initiation of the dark period. We used this

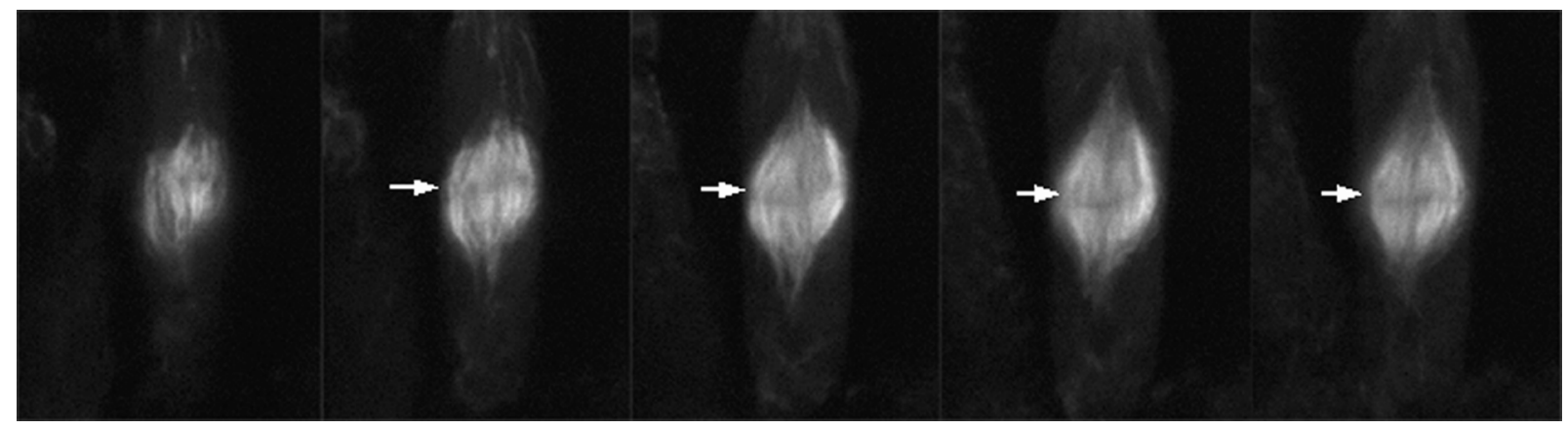

Fig. 2. Fluorescent confocal microscope image series ( $1 \mu \mathrm{m}$ sections) through Trentepohlia odorata sample labelled with anti-tubulin. Microtubules are arrayed in what appears to be a telophase microtubule system. Note the density of the microtubules appears constant throughout. A dark zone is visible at midplane (arrows). A colour version of this figure is available in IJSEM Online (http://ijs.sgmjournals.org/content/vol51/issue3/). 
information as a starting point and, with DAPIstaining protocols (López-Bautista \& Kapraun, 1995), found that under our conditions, better results were obtained $2-4 \mathrm{~h}$ after initiation of the dark period. Samples were fixed in $3.7 \%$ formalin overnight and prepared for direct immunofluorescence using the protocols in Brown \& Lemmon (1995). The cell-wallremoval cocktail consisted of $0.5 \%$ pectinase, $0.5 \%$ cellulase, $1 \%$ BSA, $10 \%$ glycerol, $1 \%$ Triton X-100 and PHEM buffer. Samples were incubated for $1.5 \mathrm{~h}$ at $37^{\circ} \mathrm{C}$ in primary monoclonal antibody, rat antitublin (Sera-Lab, from Accurate Chemical \& Scientific), followed by incubation for $3 \mathrm{~h}$ in the dark in the secondary antibody, fluorescein-conjugated goat antirat IgG (Accurate Chemical \& Scientific). Prepared samples were viewed at the University of Louisiana at Lafayette with a Bio-Rad MRC 600 confocal laser scanning microscope.

\section{RESULTS AND DISCUSSION}

As in the case of Cephaleuros parasiticus, mitotic and cytokinetic stages were very infrequently found in either the TEM or immunomicroscopy samples of Trentepohlia odorata. The one example of metaphase, seen in a TEM sample (Fig. 1), shows typical condensed chromatin, suggestions of kinetochore regions, and a relative paucity of spindle microtubules. No nuclear envelope was observed at this stage. The apparent open mitosis in Trentepohlia differs from that in Cephaleuros parasiticus, which was closed with the nuclear envelope intact, even at the poles, at metaphase (Chapman \& Henk, 1986). However, both TEM and immunolight microscopy show massive microtubular arrays at later stages of cytokinesis, consistent with phragmoplast-mediated cell divisions (Figs 2 and 3). The labelled microtubular array frequently observed in immunofluorescence (Fig. 2) is comparable to the phragmoplast microtubule system seen in TEM (e.g. Figs 3 and 4). The optical vertical sections in Fig. 2 exhibit 'the dark line' (e.g. Brown \& Lemmon, 1997b) (a less bright line) in the equatorial plane of the tubular array, which suggests fewer microtubules in this region and is comparable to the developing cell plate seen in TEM (Figs 3 and 4, and diagram Fig. 7c, d). It is clear that a massive system of microtubules arranged perpendicular to the plane of cell division is a key feature of the cytokinetic process. Interestingly, immunofluorescence shows that the orientation of the microtubules in $T$. odorata is linear, unlike those in the filamentous zygnematacean green alga, Mougeotia, in which they are more lateral in orientation (Galway \& Hardham, 1986; Grolig, 1992).

The TEM observations included a single metaphase in which the condensed chromosomes are seen (Fig. 1). Multiple observations of late telophase, wherein the daughter nuclei are reformed and widely separated by the 'double-cone' phragmoplast microtubular structure, show small vesicles aligned and fusing in the centre of the structure. A particularly interesting

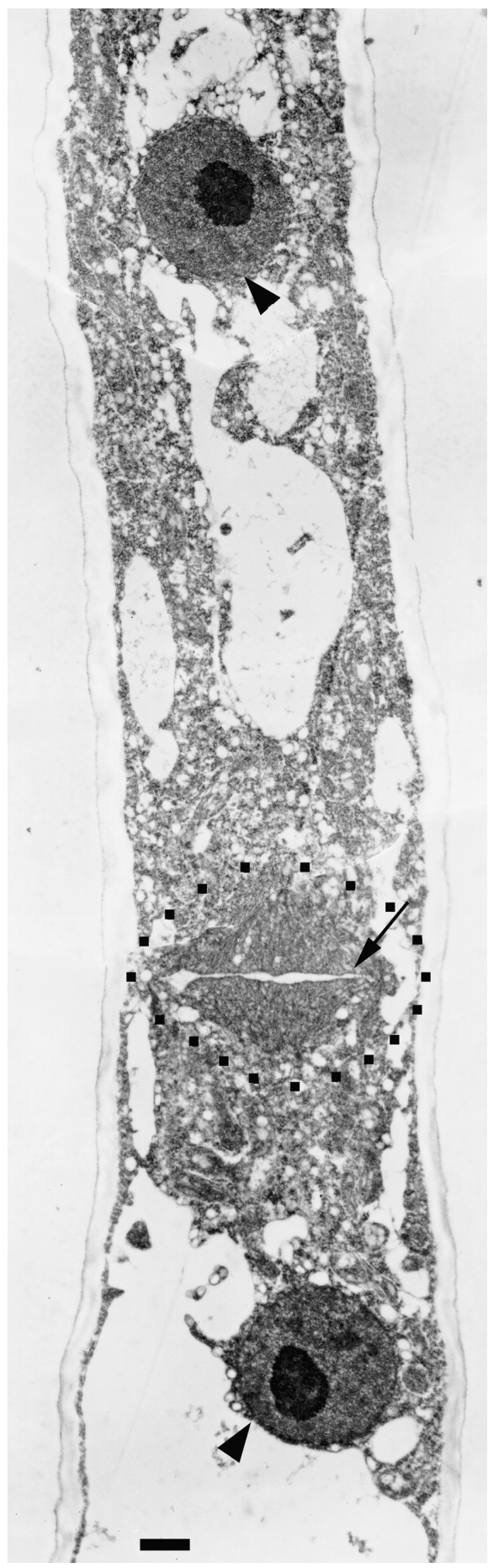

Fig. 3. Composite photograph showing parts of three separate TEM sections through the same dividing cell. (The longitudinal plane of section was not exactly parallel to the longitudinal plane of the cell.) The two mature daughter nuclei (arrowheads) are more than $20 \mu \mathrm{m}$ apart and separated by a phragmoplast (encircled by dots) consisting of microtubules, small vesicles and the nascent cell plate (arrow). Bar, $1 \mu \mathrm{m}$.

feature of this process is the fact that the fusion of phragmoplast vesicles clearly appears to be centripetal (Fig. 4). It is important to note that there is no 

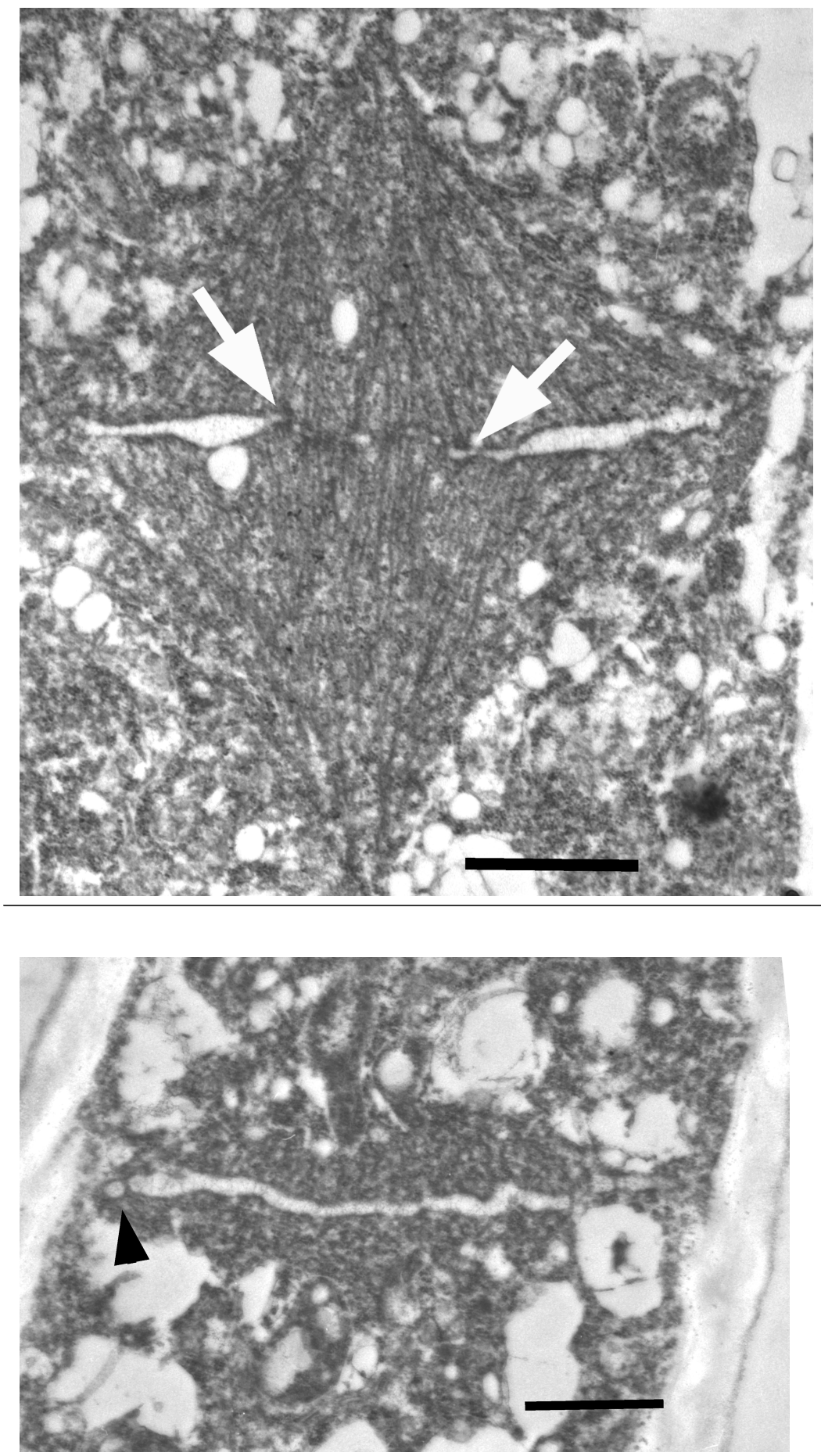

Fig. 4. Medial longitudinal TEM section through a phragmoplast at late telophase. The microtubule array is affiliated with many small vesicles which are seen to be fusing as a presumptive cell plate at the equatorial plane. The fusion process appears to occur in a centripetally directed wave, effectively sealing the 'doughnut hole' in the middle, which is still traversed by a number of microtubules in this image. Arrows mark the periphery of the central hole in the developing cell plate. Bar, $1 \mu \mathrm{m}$. centripetal infurrowing of the cell wall; rather, it is only the coalescence of phragmoplast vesicles that proceeds, at least in the early stages, centripetally (Fig. 5); a longitudinal section just inside the cell wall, shows the periphery of the fused cell plate vesicles. The developing cell plate ultimately extends centrifugally to reach and fuse with the lateral cell walls (Figs 5 and 6). As in the case of Cephaleuros parasiticus, the newly formed cell plate appears 'wavy' rather than rigidly flat (Fig. 6). In angiosperm cytokinesis (e.g. in Tradescantia, see
Bonsignore \& Hepler, 1985), a comparable (but less vigorous) undulation of the developing cell plate occurs prior to attachment to the lateral cell walls. This observation may reflect some movement of the cell plate prior to attachment to the lateral walls or incomplete polymerization of cellulose wall elements. The diagram (Fig. 7) shows the process of phragmoplast-mediated cytokinesis as documented for Cephaleuros parasiticus. For Trentepohlia odorata, stages 7(b) through 7(e) have been observed, and we cannot 


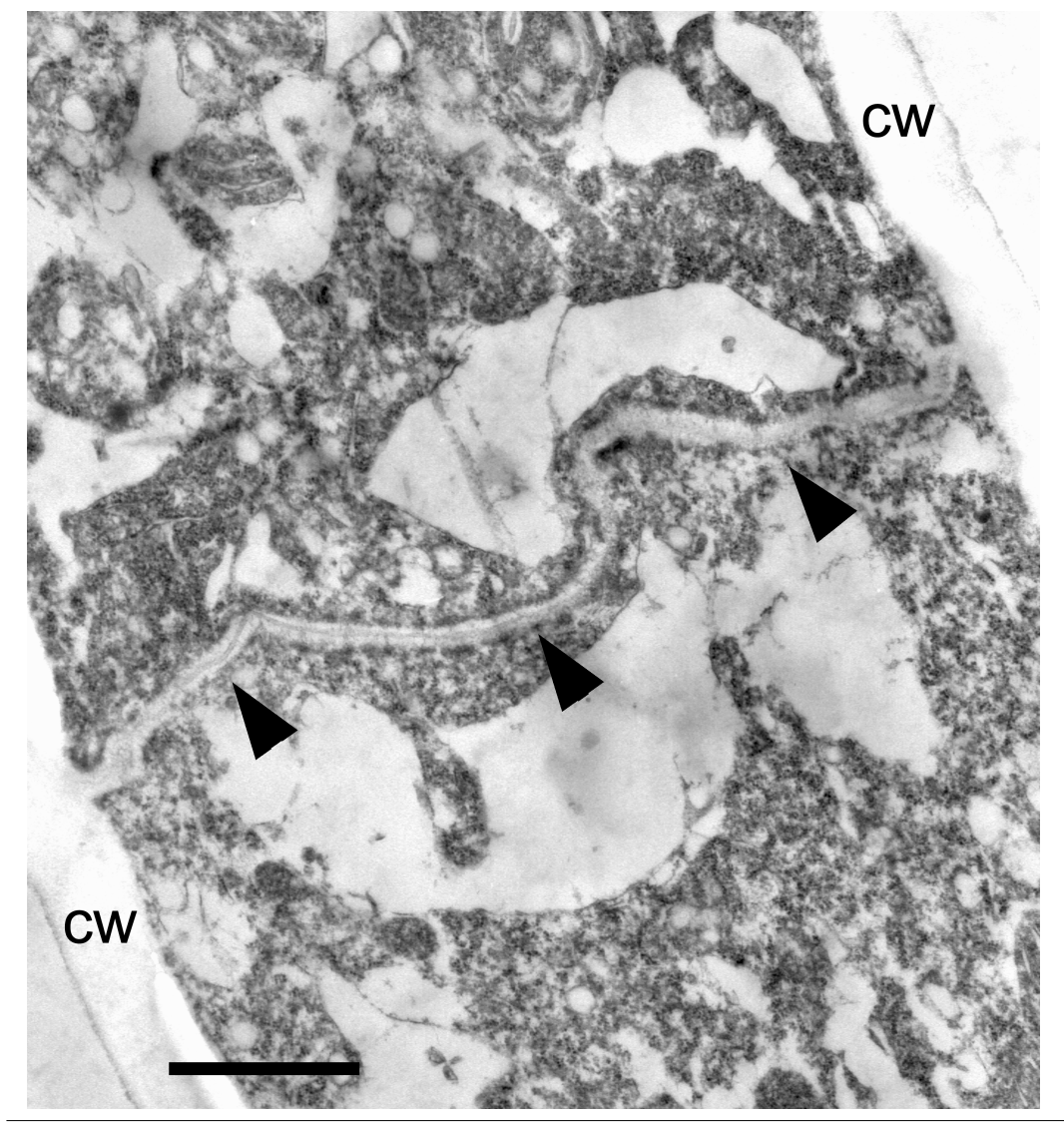

Fig. 6. TEM section through a nascent crosswall. The wall is thin and 'wavy' at this stage, perhaps due to incomplete polymerization of the newly fused cell plate material, but at least at this plane through the cell, the cross-wall is continuous with the cell wall $(\mathrm{cw})$. Bar, $1 \mu \mathrm{m}$. say for sure if a stage 'a' does or does not occur. Based on the strong similarity between those stages observed for both taxa, we speculate that overall processes are likely to be identical or nearly so. Whether or not they are identical, it is clear that vegetative cell division in both involves a massive double-cone-shaped phragmoplast microtubular structure and the coalescence of phragmoplast vesicles to form a cell plate. In neither case is there any indication whatsoever of lateral infurrowing of lateral vegetative cell walls.

The confirmation of a phragmoplast-mediated vegetative cell division in two major genera of the Trentepohliales raises the question, 'Is the phragmoplast-mediated cell division in the Trentepohliales the same as (i.e. homologous to) those of the streptophytes (i.e. charophycean green algae and the land plants), or is it a functionally similar but different (i.e. nonhomologous) cellular process?'. And similarly, 'Is the phragmoplast microtubular structure in the Trentepohliales homologous to that found in the streptophyte lineage?'. One could also pose the question of whether or not the Trentepohliales are phylogenetically charophycean algae; however, molecular systematic studies (Chapman \& Avery, 1989; Chapman et al., 1995; López-Bautista, 2000) repeatedly and robustly indicate that the Trentepohliales are ulvophycean green algae. The details of vegetative cytokinesis in Trentepohlia and Cephaleuros (e.g. the clear temporal separation of karyokinesis and cytokinesis, the distinctive double- cone microtubular structure, and the centripetal coalescence of phragmoplast vesicles) certainly indicate differences from the processes and structures observed in the streptophytes. Thus, the parallel evolution of a phragmoplast-mediated cytokinesis would seem to be the explanation for the process in one order of the chlorophycean lineage sensu lato of green algae vis-àvis the streptophyte lineage of green algae and land plants.

Among the charophycean green algae, a primitive phragmoplast has been reported in some Zygnematales (e.g. Spirogyra) that was shown to combine centripetal cell wall infurrowing with a primitive phragmoplast system (Fowke \& Pickett-Heaps, 1969a, b; Grolig, 1992). In the genus Phycopeltis, another member of the Trentepohliales, the vegetative cell divisions, especially in very young thalli, were shown by TEM to consist of infurrowed lateral cell walls connected by a much thinner, straight cross-wall (Good, 1978). Plasmodesmata were found only in the thinner central portion of the cross-wall. Although less dramatic, a similar situation was observed in the cross-walls of vegetative cells in more mature thalli. Although no stages of karyokinesis or cytokinesis were recorded, the observed morphology could certainly be the result of a combination of infurrowing and a phragmoplastmediated cell division. In fact, it would be difficult to explain the observed morphology by any other type of cell division process. 


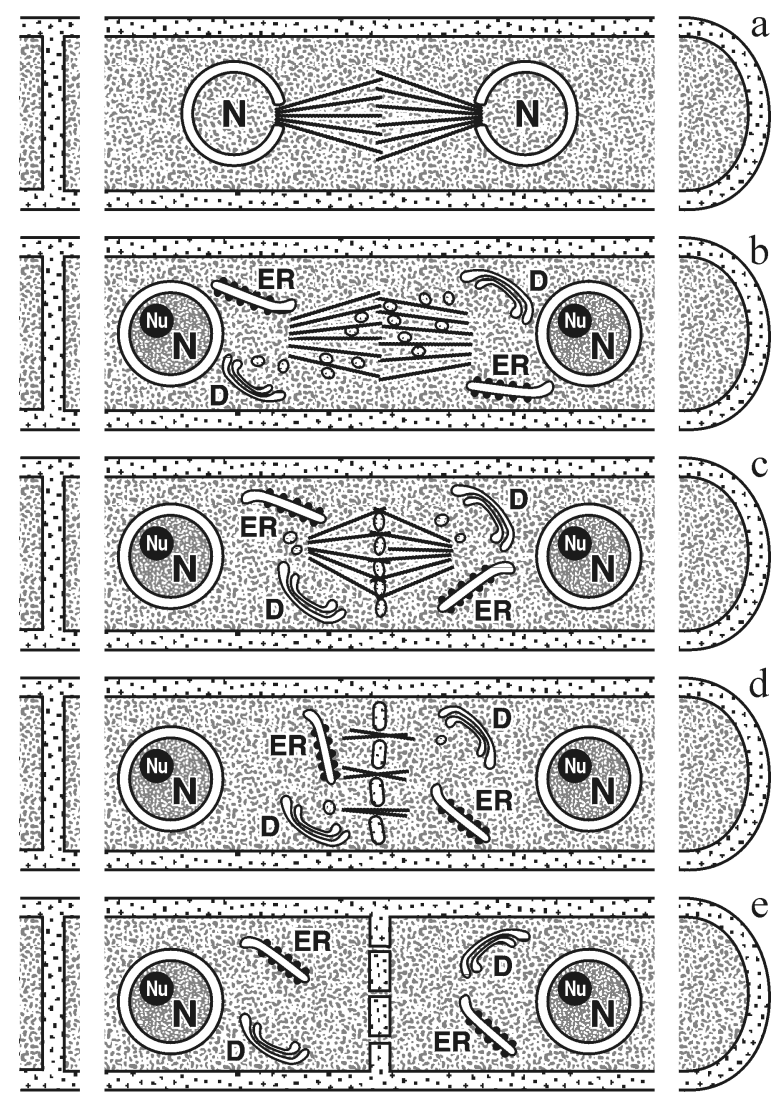

Fig. 7. Diagrams of stages of phragmoplast-mediated cytokinesis as seen in Cephaleuros parasiticus (a-e) and Trentepohlia (b-e). Bar, $1 \mu \mathrm{m}$. Drawing by Mary Lee Eggart.

Clearly, confirmation of the mode of vegetative cytokinesis in Phycopeltis would be interesting to say the least. If the hypothesized combination of cell wall infurrowing and phragmoplast formation is present, it would seem that the Trentepohliales exhibit both a primitive and a more advanced form of phragmoplastmediated cytokinesis comparable to what is found in different orders among charophycean green algae (i.e. the Zygnematales vis-à-vis the Coleochaetales and Charales). If confirmed, this evolutionary development of phragmoplast mediated cytokinesis within the Trentepohliales would be strong evidence for the nonhomology of the processes and the phragmoplast microtubular structure.

Assuming for a moment that the hypothesis of parallel evolution supported by this report is correct, the intriguing question of 'Why?' arises. Given the fact that a phragmoplast-type cytokinesis is associated with all land plants and with the subaerial Trentepohliales, one cannot avoid the seemingly wild speculation that therein lies the answer. The evolutionary history of the development of phragmoplast systems may someday be clearly documented by the analysis of the gene sequences for cytokinesis-related proteins such as phragmoplastin, which is a dynamin-like protein associated with cell plate formation in plants. It would be interesting to compare the homology or non-homology of cell plate-associated proteins from charophycean algae or land plants with those in the Trentepohliales (Zhang et al., 2000; Gu \& Verma, 1996a, b, 1997).

\section{REFERENCES}

Bonsignore, C. L. \& Hepler, P. K. (1985). Caffeine inhibition of cytokinesis: dynamics of cell plate formation-deformation in vivo. Protoplasma 129, 28-35.

Bouillon, K. (1985). Effect of photoregimes in Trentepohlia sp. (UTEX 1227) and Cephaleuros virescens Kunze. MSc thesis, Louisiana State University.

Brown, R. C. \& Lemmon, B. E. (1988). Preprophasic microtubule systems and development of the mitotic spindle in hornworts. Protoplasma 124, 175-183.

Brown, R. C. \& Lemmon, B. E. (1993). Diversity of cell division in simple land plants holds clues to evolution of the mitotic and cytokinetic apparatus in higher plants. Mem Torrey Bot Club 25, 45-62.

Brown, R. C. \& Lemmon, B. E. (1995). Methods in plant immunolight microscopy. In Methods Cell Biol 49, 86-107.

Brown, R. C. \& Lemmon, B. E. (1997a). The quadripolar microtubule system in lower land plants. J Plant Res 110, 93-106.

Brown, R. C. \& Lemmon, B. E. (1997b). Transition from mitotic apparatus to cytokinetic apparatus in pollen mitosis of the slipper orchid. Protoplasma 198, 43-52.

Brown, R. C., Lemmon, B. E. \& Graham, L. E. (1994). Morphogenetic plastid migration and microtubule arrays in mitosis and cytokinesis in the green alga Coleochaete orbicularis. Am J Bot 81, 127-133.

Chapman, R. L. \& Avery, D. (1989). Nuclear ribosomal RNA genes and the phylogeny of the Trentepohliales. $J$ Phycol $\mathbf{2 5}$ (suppl.), 8.

Chapman, R. L. \& Henk, M. C. (1986). Phragmoplasts in cytokinesis of Cephaleuros parasiticus (Chlorophyta) vegetative cells. J Phycol 22, 83-88.

Chapman, R. L., Waters, D. A. \& López-Bautista, J. M. (1995). Phylogenetic affinities of the Trentepohliales. J Phycol 31 (suppl.), 7.

Chapman, R. L., Buchheim, M. A., Delwiche, C. F. \& 8 other authors (1998). Molecular systematics of the green algae. In Molecular Systematics of Plants II, pp. 508-540. Edited by D. E. Soltis, P. S. Soltis \& J. J. Doyle. Boston: Kluwer.

Cimino, M. T., Karol, K. G., Lewandowski, J. D. \& Delwiche, C. F. (2000a). Phylogenetic relationships of Coleochaete and ChaetoSphaeridium (Coleochaetales) based on the chloroplast genes rbcL and atpB. J Phycol 36 (suppl.), 14.

Cimino, M. T., Karol, K. G. \& Delwiche, C. F. (2000b). An artifact in the small subunit rDNA sequence of Chaetosphaeridium globosum (Charophyceae, Stretophyta). J Phycol 36, 440-442.

Fowke, L. C. \& Pickett-Heaps, J. D. (1969a). Cell division in Spirogyra. I. Mitosis. J Phycol 5, 240-259.

Fowke, L. C. \& Pickett-Heaps, J. D. (1969b). Cell division in Spirogyra. II. Cytokinesis. J Phycol 5, 273-281.

Friedl, T. (1989). Comparative ultrastructure of pyrenoids in Trebouxia (Microthamniales, Chlorophyta). Plant Syst Evol 164, 145-159. 
Galway, M. E. \& Hardham, A. R. (1986). Microtubule reorganization, cell wall synthesis and establishment of the axis of elongation in regenerating protoplasts of the alga Mougeotia. Protoplasma 135, 130-143.

Good, B. H. (1978). Ultrastructural and biochemical studies on the epiphytic subaerial green alga Phycopeltis epiphyton Millardet. $\mathrm{PhD}$ thesis, Louisiana State University.

Graham, L. E. (1993). Origin of Land Plants. New York: Wiley. Graham, L. E. \& Kaneko, Y. (1991). Subcellular structures of relevance to the origin of land plants (Embryophytes) from green algae. Crit Rev Plant Sci 10, 323-342.

Grolig, F. (1992). The cytoskeleton of the Zygnemataceae. In The Cytoskeleton of the Algae, pp. 165-194. Edited by D. Menzel. Boca Raton, FL: CRC Press.

Gu, X. J. \& Verma, D. P. S. (1996a). Phragmoplastin, a dynaminlike protein associated with cell plate formation in plants. EMBO J 15, 695-704.

Gu, X. J. \& Verma, D. P. S. (1996b). Role of phragmoplastin, a dynamin-like protein, in the early cell plate formation in plants. Plant Physiol 111 (suppl.), 417.

Gu, X. J. \& Verma, D. P. S. (1997). Dynamics of phragmoplastin in living cells during cell plate formation and uncoupling of cell elongation from the plane of cell division. Plant Cell 9, 157-169.

Huss, V. A. R. \& Kranz, H. D. (1997). Charophyte evolution and the origin of land plants. Plant Syst Evol (suppl.) 11, 103-114.

Kranz, H. D., Miks, D., Siegler, M.-L., Capesius, I., Sensen, C. W. \& Huss, V. A. R. (1995). The origin of land plants: phylogenetic relationships along charophytes, bryophytes, and vascular plants inferred from complete small-subunit ribosomal RNA gene sequences. $J$ Mol Evol 41, 74-84.

López-Bautista, J. M. (2000). Molecular systematics of the green algal order Trentepohliales (Chlorophyta). $\mathrm{PhD}$ thesis, Louisiana State University.

López-Bautista, J. M. \& Kapraun, D. F. (1995). Agar analysis, nuclear genome quantification and characterization of four agarophytes (Gracilaria) from the Mexican Gulf Coast. J Appl Phycol 7, 351-357.

McCourt, R. M. (1995). Green algal phylogeny. Trends Ecol Evol 10, 159-163.

McIntosh, K., Pickett-Heaps, J. D. \& Gunning, B. E. S. (1995).
Cytokinesis in Spirogyra: integration of cleavage and cell-plate formation. Int J Plant Sci 156, 1-8.

Manhart, J. (1994). Phylogeny of green plants based on $\mathrm{rbcL}$ sequences. Mol Biol Evol 3, 114-127.

Marchant, H. J. \& Pickett-Heaps, J. D. (1973). Mitosis and cytokinesis in Coleochaete scutata. J Phycol 9, 461-471.

Mishler, B. D., Lewis, L. A., Buchheim, M. A., Renzaglia, K. S., Garbary, D. J., Delwiche, C. F., Zechman, F. W., Kantz, T. S. \& Chapman, R. L. (1994). Phylogenetic relationships of the 'green algae' and 'bryophytes'. Ann Mo Bot Gard 81, 451-483.

Nichols, H. W. (1973). Growth media - freshwater. In Handbook of Phycological Methods: Culture Methods and Growth Measurements, pp. 7-24. Edited by J. R. Stein. Cambridge: Cambridge University Press.

Panteris, E., Galatis, B. \& Apostolakos, P. (1991). Patterns of cortical and perinuclear microtubule organization in meristematic root cells of Adiantum capillus veneris. Protoplasma 165, 173-188.

Pickett-Heaps, J. D. (1967). Ultrastructure and differentiation in Chara (fibrosa). II. Mitosis. Aust J Biol Sci 20, 883-894.

Pickett-Heaps, J. D. \& Marchant, H. J. (1972). The phylogeny of the green algae: a new proposal. Cytobios 6, 255-264.

Pickett-Heaps, J. D. \& Wetherbee, R. (1987). Spindle function in the green alga Mougeotia: absence of anaphase A correlates with post-mitotic nuclear migration. Cell Motil Cytoskelet 7, 68-77.

Pickett-Heaps, J. D., Gunning, B. E. S., Brown, R. C., Lemmon, B. E. \& Cleary, A. L. (1999). The cytoplast concept in dividing plant cells: cytoplasmic domains and the evolution of spatially organized cell division. Am J Bot 86, 153-172.

Sluiman, H. J. (2000). Molecular phylogeny of Chaetosphaeridium revisited. J Phycol 36, 443-444.

Sluiman, H. J. \& Guihal, C. (1999). Phylogenetic position of Chaetosphaeridium (Chlorophyta), a basal lineage in the Charophyceae inferred from $18 \mathrm{~S}$ rDNA sequences. J Phycol 35, 395-402.

Staehelin, L. A. \& Hepler, P. K. (1996). Cytokinesis in higher plants. Cell 84, 821-824.

Zhang, Z. M., Hong, Z. L. \& Verma, D. P. S. (2000). Phragmoplastin polymerizes into spiral coiled structures via intermolecular interaction of two self-assembly domains. $J$ Biol Chem 275, 8779-8784. 